\title{
Investigation of the reasons for the failures of the tractor microclimate system
}

\author{
Victor Kataev ${ }^{1}$, Ilia Markvo*, Kaprel Khubiian ${ }^{1}$, and Valery Dimitrov ${ }^{1}$ \\ ${ }^{1}$ Don State Technical University, 1, Gagarina sq., 344003, Rostov-on-Don, Russia
}

\begin{abstract}
In the process of performing technological operations, any agricultural machinery is exposed to a large number of changing factors. The result of performing technological operations, i.e. the assessment of performance indicators, in most cases, is performed by the organoleptic method, which is characterized by a significant error (up to $40 \%$ ) and labour intensity. The use of automatic means of control gives an undoubted advantage in convenience of use and in speed of obtaining results. Given the complexity and labour intensity of assessing the quality indicators of agricultural machinery, even partial automation of this process in practice gives a significant (tens of percent) economic effect and becomes the basis for the formation of digital agriculture. We have analyzed the existing methods for controlling the quality indicators of technological operations using the example of the grain harvesting process. In particular, the possibilities of improving the methods of monitoring the quality indicators of the work of the combine harvester are considered.
\end{abstract}

\section{Introduction}

According to the Federal State Statistics Service of the Russian Federation and [1-5], over the past twenty years in the agriculture of Russia there has been a significant reduction in the number of agricultural machines, including the tractors (figure 1).

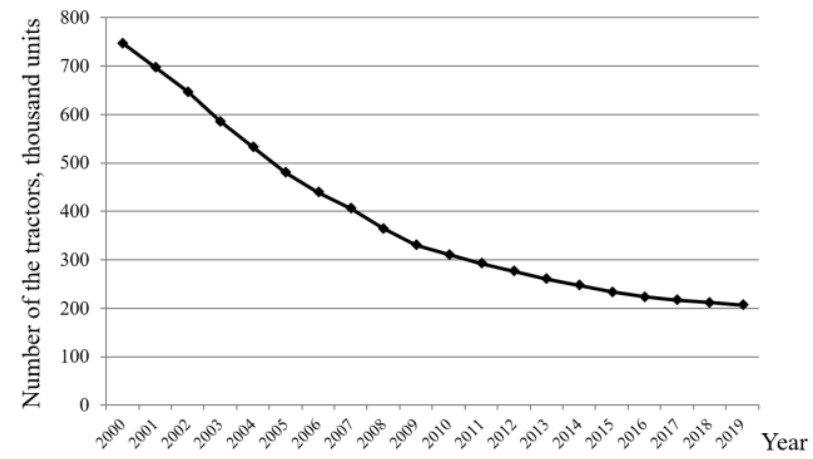

Fig. 1. The number of the tractors in the agricultural enterprises in Russia by years.

\footnotetext{
* Corresponding author: iluhan_markvo@mail.ru
} 
This trend is fully valid only for agricultural enterprises, excluding peasant farms and micro-enterprises.

Also, for large agricultural enterprises, there is a tendency towards a decrease in the coefficient of renewal of the tractor fleet (figure 2). That is, enterprises write off less equipment.

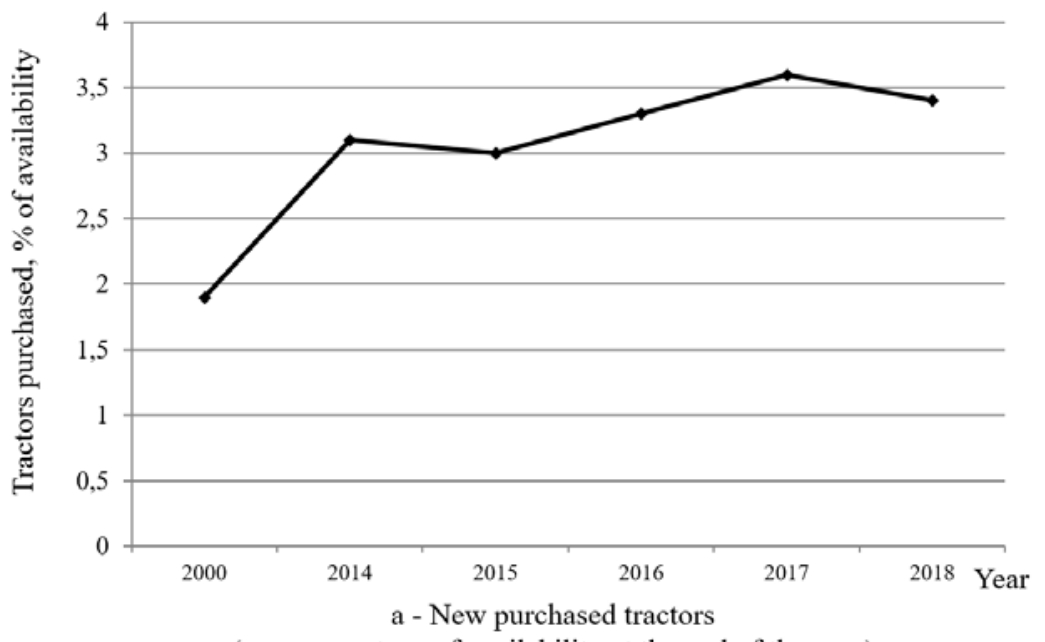

(as a percentage of availability at the end of the year)

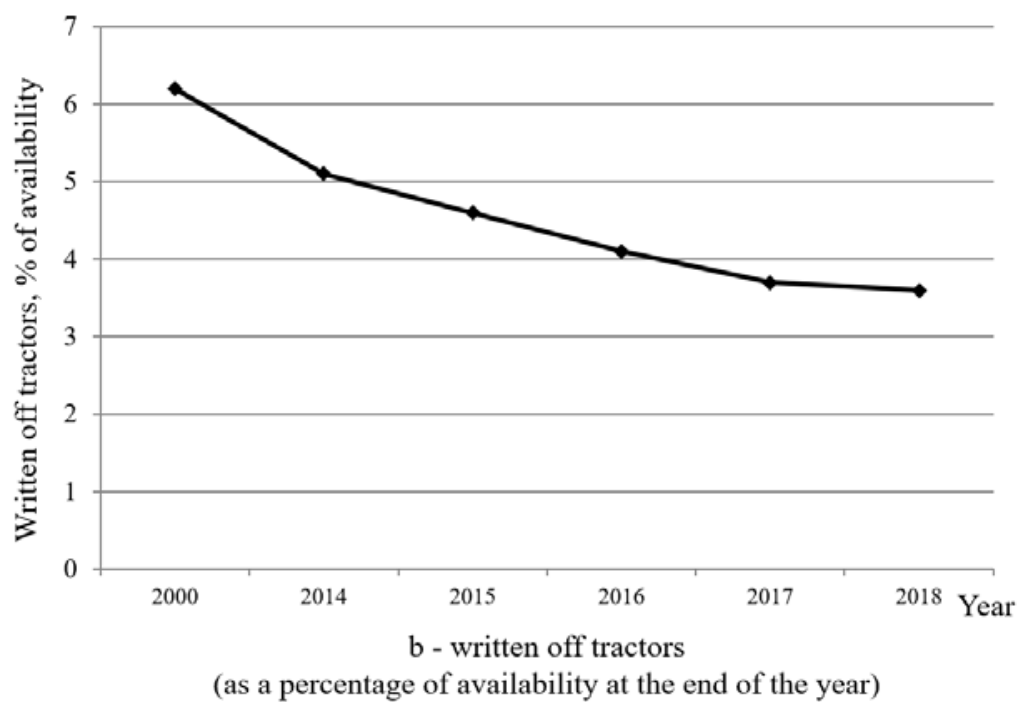

Fig. 2. The renewal of the tractor fleet in agricultural enterprises in Russia by years.

However, the write-off by agricultural enterprises of more than five hundred thousand units of the tractors over the past twenty years does not mean that they have been completely decommissioned. Many machines have been sold and now are operated by peasant farms.

According to the reports from the Russian Ministry of Agriculture, the share of the tractors with a service life of more than 10 years is seventy percent of the total fleet.

At the moment, in the Russian market for the maintenance of agricultural machines, there is an increased demand for re-equipment of the old tractors and equipping them with modern technical systems, including the microclimate system (air conditioners) [6-8]. 
The thing is that one of the most popular models in its class are the MTZ-80 and HTZ T-150 tractors, developed and produced in the Soviet Union at the Minsk and Kharkov Tractor Plants. Even modern models of machines from these manufacturers are not always equipped with the microclimate system (air conditioners), and the machines with a service life of more than 5 years, in principle, were not equipped with such systems at the manufacturer plant.

The main performers of the work on the installation of the microclimate system in the used tractors are small service organizations that use technologies and installation designs of their internal development, not coordinated with the manufacturer plant.

Over the past ten years, we have gained a certain experience in the installation and maintenance of the microclimate system installed on the machines for which this is not provided by the manufacturer. This paper presents data on the failures of the tractor microclimate system and the results of the analysis of the causes of their occurrence.

As part of our research, we tried to find out the most frequent causes of the failures of the tractor microclimate system with operating time and outline the ways to improve the reliability of such systems [9-13].

\section{Research status and work relevance}

In this study, the microclimate system of the tractors HTZ T-150 of a non-factory installation were considered (manufacturers of the tractors of this modification have been installing the microclimate system only for the last 3 to 5 years and only by special order). As part of the study, 64 machines were monitored (data on the failures over the last 3 years were considered: from April 2018 to November 2020). Among them there are 38 wheeled tractors and 26 traked tractors. The service life of the tractors varies from 5 to 30 years (some machines have been overhauled).

The distribution of the studied tractors by service life is shown in figure 3 .

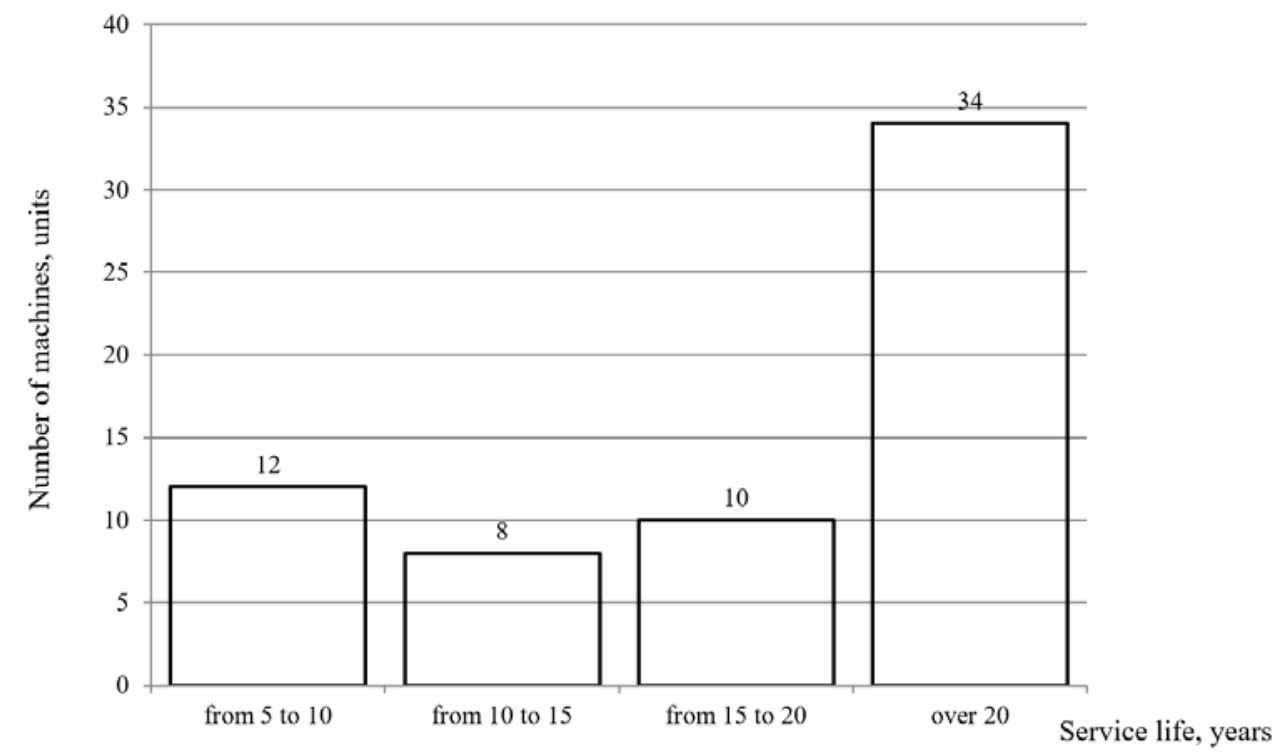

Fig. 3. The distribution of the studied tractors by service life.

The data on the statistics of the failures of the tractor microclimate system are presented in Table 1. The data are presented based on the results of the observations in the period from 04.2018 to 11.2020 . 
Table 1. The data on the failures of the tractor microclimate system during 2018-2020.

\begin{tabular}{|c|c|c|c|}
\hline $\begin{array}{l}\text { Defect } \\
\text { code }\end{array}$ & $\begin{array}{l}\text { External sign of } \\
\text { malfunction }\end{array}$ & Reason & $\begin{array}{c}\text { Number } \\
\text { of the } \\
\text { cases }\end{array}$ \\
\hline $1 \mathrm{a}$ & \multirow{2}{*}{$\begin{array}{l}\text { The electromagnetic } \\
\text { clutch of the compressor } \\
\text { does not turn on/off } \\
\text { when the temperature in } \\
\text { the cabin changes }\end{array}$} & Defective thermostat & 81 \\
\hline $1 b$ & & $\begin{array}{l}\text { Failure of electrical circuits/electrical equipment of } \\
\text { the air conditioning system }\end{array}$ & 11 \\
\hline $2 \mathrm{a}$ & \multirow{3}{*}{$\begin{array}{l}\text { Reduced cooling } \\
\text { capacity }\end{array}$} & Too much oil in the system & 5 \\
\hline $2 b$ & & Clogging/destruction of the receiver-drier & 6 \\
\hline $2 \mathrm{c}$ & & $\begin{array}{l}\text { Clogged (dirty) condenser (freon does not cool down } \\
\text { and does not condense) }\end{array}$ & 15 \\
\hline $3 \mathrm{a}$ & \multirow{5}{*}{ Freon leak } & Mechanical damage (chafing) of the connecting hoses & 9 \\
\hline $3 b$ & & Mechanical damage (cracks) of the evaporator tubes & 49 \\
\hline $3 \mathrm{c}$ & & Mechanical damage to the capacitor & 4 \\
\hline $3 \mathrm{~d}$ & & Loss of tightness of connections & 11 \\
\hline $3 e$ & & Freon leak through the compressor shaft seal & 7 \\
\hline 4 & $\begin{array}{l}\text { Destruction of fasteners } \\
\text { or compressor drive }\end{array}$ & $\begin{array}{l}\text { Loosening of threaded connections of fasteners and } \\
\text { belt tensioning/stretching devices }\end{array}$ & 9 \\
\hline
\end{tabular}

For a visual representation of the frequency of occurrence of the causes of the failures, a Pareto diagram was built [14-15] (figure 4).

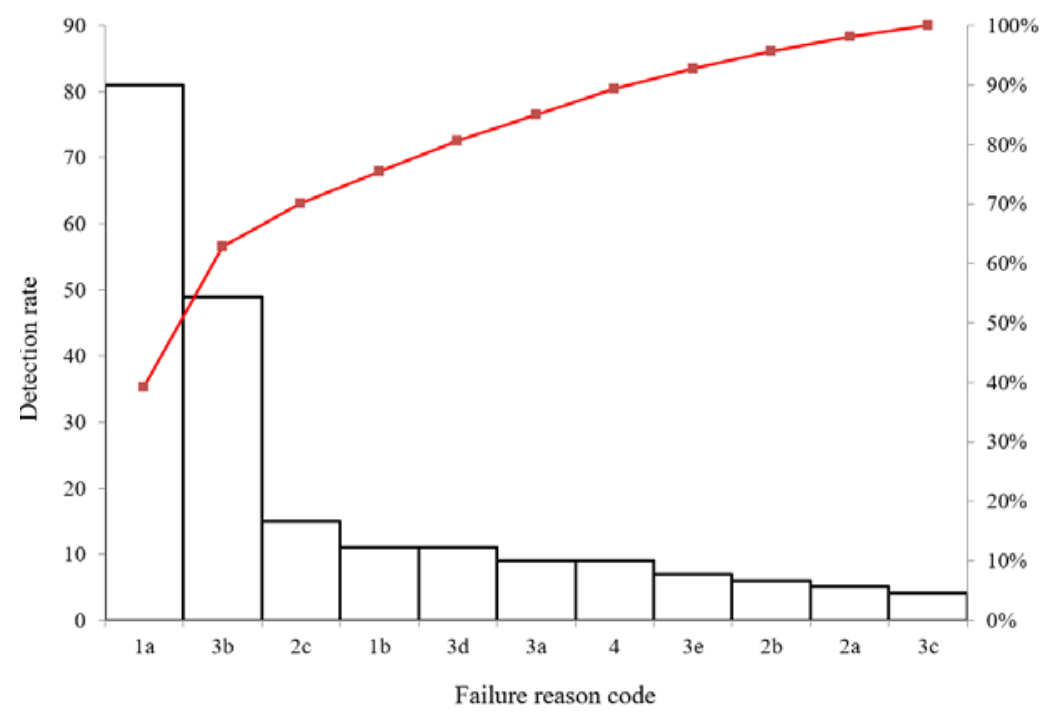

Fig. 4. The Pareto diagram of the causes of the failures of the microclimate system of the tractors (defect codes (the reason for the failure) according to table 1).

The diagram shows that seventy percent of the failures are due to the causes 1a (Defective thermostat), 3b (Mechanical damage (cracks) in the evaporator tubes) and 2c (Clogged (dirty) condenser). In the framework of our research, it was decided to focus on these causes of the failure and determine why they occur and how to reduce the risk of their occurrence. 
The reason for the failure $2 \mathrm{c}$ (clogged (dirty) condenser) is that the soil cultivation processes are accompanied by a large amount of dust and dirt, which clog up in the condenser lamellae. The daily maintenance operation includes cleaning the radiator block (the air conditioner condenser is located in it) with a stream of air under pressure.

To determine the causes of the failures $1 \mathrm{a}$ and $3 \mathrm{~b}$, the failure data was stratified. For the failure reason 1a, the following grounds for data stratification were identified:

- type of thermostat (electronic or mechanical);

- method of connection to the control circuit (directly to the electromagnetic clutch or through a relay/diode block).

For the failure reason $3 \mathrm{~b}$, the following grounds for data stratification were identified:

- type of tractor (wheeled or tracked);

- the place of occurrence of mechanical damage (from the side of the connection with the hoses or from the side of the front panel of the evaporator);

- location of the evaporator (under the dashboard to the left of the driver's seat or under the cab ceiling).

The next subsection of the paper presents the obtained results and the analysis of the identified inconsistencies.

\section{Results and discussion}

The stratification results are presented in tables 2, 3 and in figures 5, 6 .

Table 2. The results of stratification of data on the failures of the thermostats of the microclimate system.

\begin{tabular}{|c|c|c|c|c|}
\hline \multirow[b]{2}{*}{$\begin{array}{c}\text { Thermostat } \\
\text { type }\end{array}$} & \multirow[b]{2}{*}{$\begin{array}{c}\text { Number of } \\
\text { machines }\end{array}$} & \multicolumn{3}{|c|}{ Failure amount } \\
\hline & & $\begin{array}{l}\text { Way of connection to a } \\
\text { control circuit without a } \\
\text { relay }\end{array}$ & $\begin{array}{l}\text { Way of connection to a } \\
\text { control circuit through a } \\
\text { relay }\end{array}$ & $\begin{array}{l}\text { Total number of } \\
\text { the cases }\end{array}$ \\
\hline Electronic & 38 & $\begin{array}{c}66 \\
\text { (installed on } 20 \\
\text { machines) }\end{array}$ & $\begin{array}{c}5 \\
\text { (installed on } 18 \\
\text { machines) }\end{array}$ & 71 \\
\hline Mechanical & 26 & $\begin{array}{c}10 \\
\text { (installed on } 26 \\
\text { machines) }\end{array}$ & $\begin{array}{c}0 \\
\text { (installed on } 0 \text { machines) }\end{array}$ & 10 \\
\hline
\end{tabular}

Table 3. The results of stratification of data on mechanical damage to evaporator tubes.

\begin{tabular}{|c|c|c|c|c|c|c|}
\hline \multirow{3}{*}{$\begin{array}{c}\text { Tractor } \\
\text { type }\end{array}$} & \multirow{3}{*}{$\begin{array}{l}\text { Number of } \\
\text { machines }\end{array}$} & \multicolumn{5}{|c|}{ Number of cases of mechanical damage to the evaporator tubes } \\
\hline & & \multicolumn{2}{|c|}{ Evaporator location } & \multicolumn{2}{|c|}{ Localization of damage } & \multirow[b]{2}{*}{$\begin{array}{c}\text { Total } \\
\text { number of } \\
\text { the cases }\end{array}$} \\
\hline & & $\begin{array}{l}\text { Under the } \\
\text { dashboard }\end{array}$ & $\begin{array}{l}\text { Under the } \\
\text { cabin } \\
\text { ceiling }\end{array}$ & $\begin{array}{l}\text { from the side } \\
\text { of connection } \\
\text { with hoses }\end{array}$ & $\begin{array}{l}\text { from the side } \\
\text { of the front } \\
\text { panel }\end{array}$ & \\
\hline Wheeled & 38 & 3 & 1 & 3 & 1 & 4 \\
\hline Tracked & 26 & 40 & 0 & 40 & 5 & 45 \\
\hline
\end{tabular}




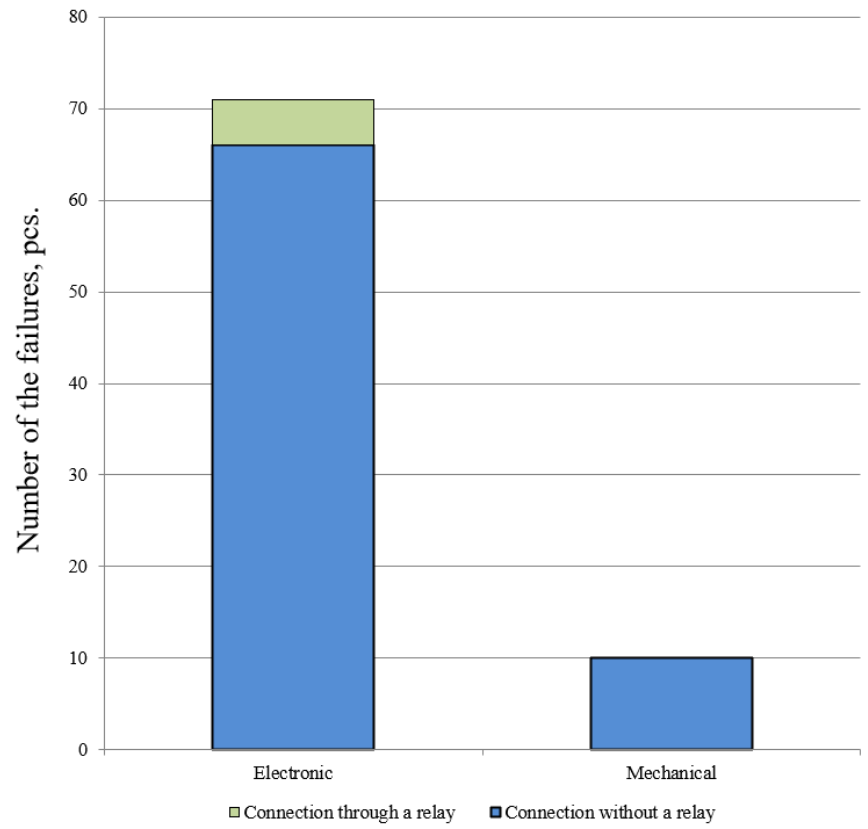

Thermostat type and the way of inclusion in the control circuit

Fig. 5. The results of stratification of data on the failures of the thermostats of the microclimate system (according to table 2).

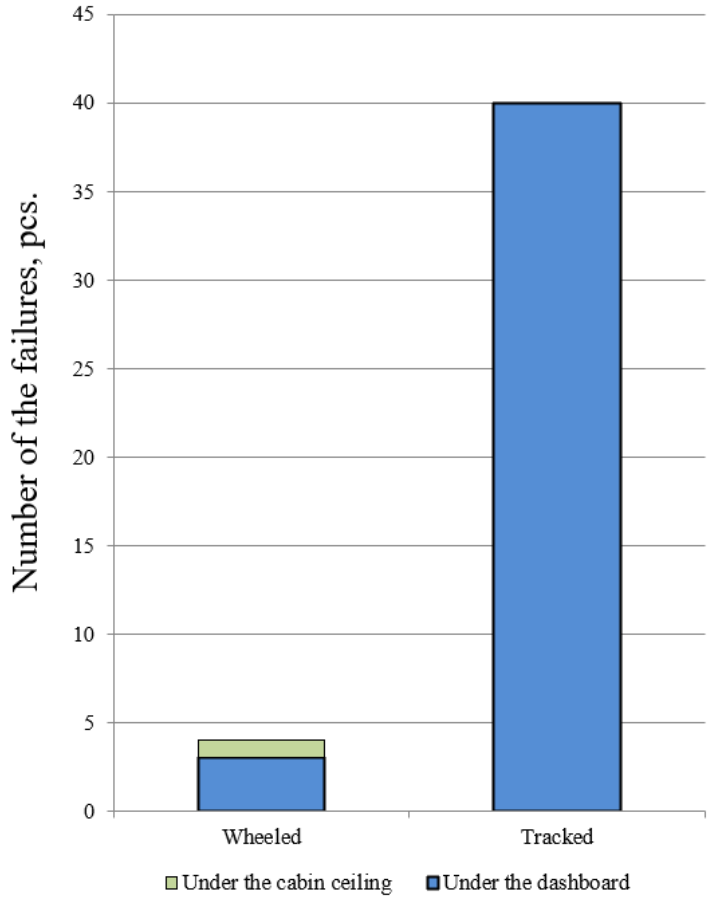

Tractor type and evaporator location

Fig. 6. The results of stratification of data on mechanical damage to evaporator tubes (according to table 3$)$. 
The presented results of data stratification on the microclimate system the failures allow us to make an unambiguous conclusion that the failure 1a (Thermostat is defective) most often occurs when electronic thermostats are connected to the control circuit of the electromagnetic clutch of the air conditioner compressor "directly" without a relay and/or diode unit.

The failure of the air conditioning system in the considered tractors 3b (Mechanical damage (cracks) of the evaporator tubes) is mainly observed on the tracked tractors. In this case, the failure is localized in the area where the evaporator is connected to the hoses (especially the hose of the low pressure circuit) through which the working gas (freon) is supplied/removed.

The performed analysis of the reasons for the failures of the tractor microclimate system installed on the HTZ T-150 tractor made it possible to make the following conclusions:

1. Electronic thermostats of the microclimate system of mobile equipment are very sensitive to current loads; therefore it is unacceptable to include them in the circuit "directly" without using a relay. Older mechanical thermostats tolerate high electrical currents much more easily, so direct connection circuits in the electromagnetic clutch control circuit of an air conditioning compressor were economically justified, as they provided acceptable reliability while reducing the costs on the component.

2. Apparently, the design of the tracked vehicles causes a stronger vibration during operation, which leads to mechanical damage to the evaporator tubes of the air conditioner. Installation of the evaporator under the dashboard requires a very tight connection between the connecting hoses and the evaporator. This is due to the fact that the evaporator is located quite low above the floor of the cabin, and in order to connect it to the hoses, the latter have to be bent significantly, and the connecting hoses are quite inelastic. As a result, all vibration effects are transmitted through the inelastic interaction of the connecting hoses and fittings soldered to the evaporator tubes, which leads to the fatigue failure of the tubes. To eliminate the causes of such a discrepancy, the evaporator should be located under the ceiling of the tracked tractor cabin.

\section{References}

1. G. Molari, M. Mattetti, S. Fiorati, Biosystems Engineering, 187, 160-170, (2019) DOI:10.1016/j.biosystemseng.2019.09.001

2. K. Durczak, A. Ekielski, K. Pilarski, Heliyon, 6 (10), e05039 (2020) DOI:10.1016/j.heliyon.2020.e05039

3. Y.Y. Hilal, S.A. Jabbar Al-rajabo, G. A. Dahham, Soil and Tillage Research, 205, 104806 (2021) DOI:10.1016/j.still.2020.104806

4. V. Kataev, I. Markvo, K. Khubiian, E. Zubrilina, E3S Web of Conferences, 175, 05034 (2020) DOI:10.1051/e3sconf/202017505034

5. W.-S.Kim, Y.-J. Kim, Ch.-H. Choi, Journal of Terramechanics, 94, 13-22 (2021) DOI: 10.1016/j.jterra.2020.11.005

6. J. Oh, K. Choi, Y.-J. Kim, Computers and Electronics in Agriculture, 169, 105199 (2020) DOI:10.1016/j.compag.2019.105199

7. V. Kataev, I. Markvo, K. Khubiian, V. Dimitrov, E3S Web of Conferences, 175, 05005 (2020) DOI:10.1051/e3sconf/202017505005

8. S. M. Ali, A. Chakraborty, Applied Thermal Engineering, 90, 54-63 (2015) DOI:10.1016/j.applthermaleng.2015.06.078

9. M. Hosseinpour-Zarnaqa, M. Omida, E. Biabani-Aghdamb, Information Processing in Agriculture (2021) DOI:10.1016/j.inpa.2021.01.002 
10. M. A. Lopez-Campos, A. C.Marquez, J. F. Gomez Fernandez, Advanced Maintenance Modelling for Asset Management (2017) DOI:10.1007/978-3-319-58045-6_3

11. W.Zhang, X. Li, Q. Ding, ISA Transactions, 95, 295-305 (2019) DOI:10.1016/j.isatra.2018.12.025

12. V. Kataev, I. Markvo, K. Khubiian, E. Zubrilina, E3S Web of Conferences, 210, 05009 (2020) DOI:10.1051/e3sconf/202021005009

13. G. Qiu, Y. Gu, Q. Cai, Measurement, 145, 94-107 (2019) DOI:10.1016/j.measurement.2019.05.057

14. R. Ziani, H. Mahgoun, S. Fedala, A. Felkaoui, Sign Proc Appl Rotating Mach Diag, 115 (2017)

15. I. Markvo, E.Zubrilina, V. Novikov, E3S Web of Conferences, 126, 00054 (2019) DOI: $10.1051 /$ e3sconf/201912600054 